\title{
Penerapan Metode Particle Swarm Optimization Pada Optimasi Prediksi Pemasaran Langsung
}

\author{
Yuni Eka Achyani
}

STMIK Nusa Mandiri Jakarta

e-mail: arizu.yea@gmail.com

\begin{abstract}
Abstrak
Dalam persaingan ketat saat ini, promosi yang baik dapat memberikan kredibilitas untuk produk baru. Promosi perlu mendapat perhatian lebih dan serius, karena dalam kehidupan sehari-hari timbul produk unggulan, jika tidak mengetahuinya, kemungkinan produk yang ditawarkan kepada konsumen kurang ditanggapi oleh pasar, oleh karena itu perusahaan harus mengupayakan produknya, meyakinkan dan mempengaruhi konsumen untuk menciptakan permintaan akan produk ini. Langkah yang bisa dilakukan oleh perusahaan untuk melakukannya adalah dengan melakukan pemasaran langsung. Peningkatan akurasi prediksi pemasaran langsung dapat dilakukan dengan cara melakukan seleksi terhadap atribut, karena seleksi atribut mengurangi dimensi dari data sehingga operasi algoritma data mining dapat berjalan lebih efektif dan lebih cepat. Dalam penelitian ini akan digunakan metode support vector machine dan akan dilakukan seleksi atribut dengan menggunakan particle swarm optimization untuk prediksi pemasaran langsung. Setelah dilakukan pengujian maka hasil yang didapat adalah support vector machine menghasilkan nilai akurasi sebesar $88,71 \%$, nilai precision $89,47 \%$ dan nilai AUC sebesar 0,896. Kemudian dilakukan seleksi atribut dengan menggunakan particle swarm optimization dimana atribut yang semula berjumlah 16 variabel prediktor terpilih 12 atribut yang digunakan. Hasil menunjukkan nilai akurasi yang lebih tinggi yaitu sebesar $89,38 \%$, nilai precision $89,89 \%$ dan nilai AUC sebesar 0,909 dengan nilai akurasi klasifikasi sangat baik (excellent clasiffication). Sehingga dicapai peningkatan akurasi sebesar $0,67 \%$, dan peningkatan AUC sebesar 0,013.
\end{abstract}

Kata Kunci: Particle Swarm Optimization, Pemasaran Langsung, Seleksi Atribut

\begin{abstract}
In the current intense competition a good promotion can provide credibility for a new product. Promotion needs to get more attention and serious, because in everyday life arise a prime product, if not find out, the possibility of products offered to consumers less responded by the market, therefore the company should strive for its products. , convincing, and influencing consumers to create demand for these products. Steps that can be done by the company to do so is to do direct marketing. Increased accuracy of direct marketing predictions can be done by selecting attributes, because of the selection. Data mining can run more effectively and quickly. In this study the method to be used is. With particle swarm optimization for direct marketing prediction optimization. After testing, the results obtained are support vector engine yield value of $88.71 \%$, precision value $89.47 \%$ and AUC value of 0.896 . Then the attribute selection is done using particle swarm optimization where the original attribute uses 16 predictor variables selected 12 attributes used. The results showed a higher value of $89.38 \%, 89.89 \%$ accuracy and $A U C$ value of 0.909 with very good fair value (excellent classification). The price increase is $0.67 \%$, and the increase of $A U C$ is 0,013 .
\end{abstract}

Keywords: Particle Swarm Optimization, Direct Marketing, Selection Attributes.

\section{Pendahuluan}

Pemasaran produk merupakan salah satu kunci untuk memaksimumkan tujuan perusahaan dalam menghasilkan laba. Tanpa adanya pemasaran maka usaha/bisnis yang kita jalankan tidak akan berkembang pesat. Secara umum, tujuan direct marketing adalah untuk memasarkan produk atau jasa kepada target konsumen dengan biaya pemasaran yang lebih minim. Direct marketing memberikan manfat kepada beberapa oknum yang terlibat didalamnya, yaitu pemilik produk, penjual dan konsumen (Kotler, Armstrong, Ang, Leong, Tan, \& Tse, 2005). 
Pelaksanaan pemasaran langsung dari waktu ke waktu menghasilkan data dan informasi dalam bentuk laporan yang perlu dianalisis oleh manager dalam rangka mendukung keputusan. Namun, itu adalah tugas yang sulit bagi manusia untuk menganalisis data yang kompleks yang luas. Kesulitan ini menyebabkan perkembangan teknik intelegen bisnis, yang bertujuan mengekstraksi pengetahuan yang berguna untuk mendukung pengambilan keputusan.

Salah satu cara yang efektif untuk menganalisa laporan dari kampanye sebelumnya dan serupa dalam mencari tren dan pola adalah melalui teknik data mining, untuk membangun model dan kemudian ekstrak pengetahuan.

Marketing memiliki sedikit pengetahuan tentang data mining, maka ada kebutuhan untuk mengembangkan suatu kerangka kerja yang disederhanakan untuk membantu marketing dalam memanfaatkan metode data mining untuk pemasaran langsung. Beberapa studi yang dilakukan untuk memprediksi pemasaran dengan metode komputasi antara lain: support vector machine (SVM) (Moro \& Laureano, 2012)dan multi layer perceptron (MLP) (Elsalamony \& Elsayad, 2013).

Klasifikasi merupakan topik yang penting dalam penelitian data mining. Dimana terdiri dari sekumpulan data yang masing-masing sudah dikelompokkan kedalam kelas tertentu, masalah klasifikasi yang diperhatikan yaitu dengan penentuan aturan yang memungkinkan adanya klasifikasi walaupun data yang ada belum menunjukkan hal tersebut.

SVM telah berhasil diaplikasikan dalam problema dunia nyata (real-world problems), dan secara umum memberikan solusi yang lebih baik dibandingkan metode konvensional seperti misalnya artificial neural network. SVM dapat mengatasi masalah klasifikasi dan regresi dengan linier ataupun nonlinier kernel yang dapat menjadi satu kemampuan algoritma pembelajaran untuk klasifikasi serta regresi. SVM juga memiliki akurasi tinggi dan tingkat kesalahan yang relative kecil, kemampuan untuk mengatasi overfitting tidak membutuhkan data yang terlalu besar dan dapat digunakan untuk melakukan prediksi.

Particle Swarm Optimization merupakan salah satu algoritma optimasi yang dapat digunakan untuk pengambilan keputusan. Algoritma ini bekerja dengan cara menghitung secara terus menerus calon solusi dengan menggunakan suatu acuan kualitas. Algoritma ini mengoptimasi permasalahan dengan cara menggerakkan partikel didalam ruangan permasalahan menggunakan fungsi tertentu.

Karena konsep sederhana, implementasi mudah, dan konvergensi cepat, particle swarm optimization (PSO) dapat diterapkan untuk berbagai aplikasi di berbagai bidang untuk memecahkan masalah optimasi. Implementasi PSO sangat mudah dan hanya dibutuhkan beberapa baris kode pemrograman, dan juga tidak dibutuhkannya operator matematika yang rumit, maka dari itu dapat mengefesienkan perhitungan baik dari segi memori yang di butuhkan dan juga dari segi kecepatan. PSO, sebagai alat optimasi, yang dapat membantu menentukan parameter optimum. Tetapi PSO memiliki ketergantungan yang sensitif pada parameter yang digunakan (Yusup, Zain, Zaiton, \& \& Hashim, 2012).

Berdasarkan uraian dan permasalahan di atas maka, penulis memutuskan untuk menggunakan klasifikasi Support Vector Machine (SVM) untuk membentuk model prediksi pemasaran langsung, serta membantu mengolah data numerik dan memilih atribut yang baik, kemudian menggunakan algoritma Particle Swarm Optimization (PSO) untuk penerapan optimasi untuk seleksi atribut dalam penentuan model prediksi pemasaran langsung sehingga akan diperoleh peningkatan akurasi.

Data mining merupakan disiplin ilmu yang mempelajari metode untuk mengekstrak pengetahuan atau menemukan pola dari suatu data. Data mining merupakan bagian dari proses Knowledge Discovery from Data (KDD). proses penjelajahan pengetahuan dimulai dari beberapa database dilakukan proses cleaning dan integration sehingga menghasilkan data warehouse. Dilakukan proses selection dan transformation yang kemudian disebut sebagai data mining hingga menemukan pola dan memperoleh pengetahuan dari data (knowledge).

Tahapan data mining dalam proses penemuan pengetahuan (Han \& Kamber, 2007): 
1. Pembersihan data (untuk menghilangkan noise dan data tidak konsisten)

2. Integrasi data (di mana beberapa sumber data dapat dikombinasikan)

3. Data seleksi (di mana data yang relevan dengan tugas analisis basis data yang akan diambil)

4. Data transformasi (dimana data diubah atau dikonsolidasikan ke dalam bentuk yang sesuai untuk pertambangan dengan melakukan operasi ringkasan atau agregasi)

5. Data mining (proses esensial dimana metode cerdas diaplikasikan untuk mengekstrak pola data)

6. Pola evaluasi (untuk mengidentifikasi pola yang benar-benar menarik yang mewakili pengetahuan didasarkan pada beberapa langkahlangkah interestingness).

7. Pengetahuan presentasi (dimana visualisasi dan teknik representasi pengetahuan digunakan untuk menyajikan pengetahuan ditambang kepada pengguna).

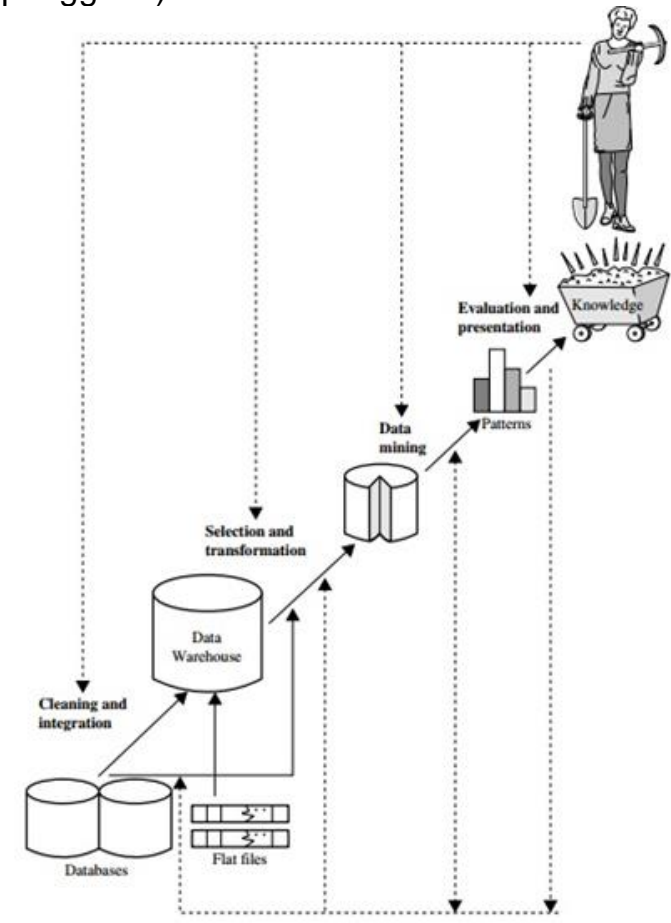

Gambar 1. Tahapan data mining

Sumber: Han \& Kamber, 2007

Support Vector Machine adalah metode learning machine yang bekerja atas prinsip Structural Risk Minimization (SRM) dengan tujuan menemukan hyperplane terbaik yang memisahkan dua buah class pada input space (Bellotti \& Crook, 2007). Hyperplane terbaik adalah hyperplane yang terletak ditengah-tengah antara dua set obyek dari dua class. Hyperplane pemisah terbaik antara kedua class dapat ditemukan dengan mengukur margin hyperplane tersebut dan mencari titik maksimalnya. Margin adalah jarak antara hyperplane tersebut dengan pattern terdekat dari masing-masing class. Pattern yang paling dekat ini disebut sebagai support vector (Aydin, Karakose, \& Akin, 2011).

Menurut (Yin, X., Chai, \& Fang, 2015) Support Vector Machine (SVM) adalah suatu metode klasifikasi untuk mencari nilai hyperplane terbaik yang mampu menemukan solusi global optimal. Sehingga nilai akurasi tidak mudah berubah-ubah.

Secara sederhana konsep SVM adalah sebagai usaha mencari hyperlane terbaik yang berfungsi sebagai pemisah dua buah class pada input space, dimana dapat dilihat pada gambar dibawah ini:
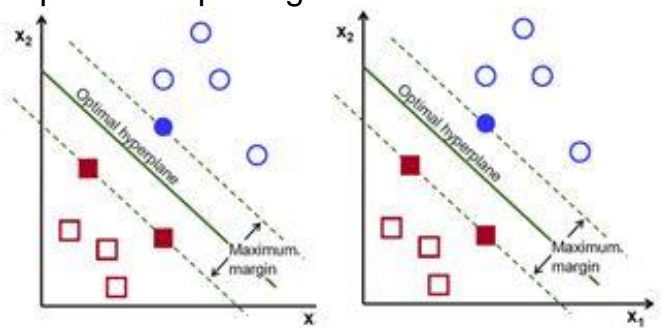

Tujuan seleksi atribut adalah untuk pengurangan atribut dari dataset untuk menghilangkan variabel yang dianggap tidak relevan. Metode seleksi fitur dapat diklasifikasikan ke dalam tiga kategori utama (Vercellis, 2009):

1. Metode filter

Metode Filter adalah memilih atribut yang relevan sebelum pindah ke tahap pembelajaran berikutnya, atribut yang dianggap paling penting yang dipilih untuk pembelajar, sedangkan sisanya dikecualikan.

2. Metode wrapper

Metode wrapper menilai sekelompok variabel dengan menggunakan klasifikasi yang sama atau algoritma regresi digunakan untuk memprediksi nilai dari variabel target.

\section{Metode embedded}

Untuk metode embedded, proses seleksi atribut terletak di dalam algoritma pembelajaran, sehingga pemilihan set optimal atribut secara langsung dibuat selama fase generasi model.

Di sisi lain, seleksi atribut adalah proses yang mahal, dan juga bertentangan dengan asumsi awal yaitu bahwa semua 
informasi atau atribut diperlukan dalam rangka mencapai akurasi maksimal. Ada empat alasan utama untuk melakukan pengurangan dimensi yaitu (Maimon \& Rokach, 2010):

1. Penurunan biaya model pembelajaran

2. Meningkatkan kinerja model pembelajaran

3. Mengurangi dimensi yang tidak relevan

4. Mengurangi dimensi yang berlebihan
Particle Swarm Optimization (PSO) merupakan teknik optimasi heuristic global yang diperkenalkan oleh Dokter Kennedy dan Eberhart pada tahun 1995 yang terinspirasi oleh perilaku sosial kawanan burung yang mencoba mencapai tujuan yang tidak di ketahui.

Berikut adalah beberapa penelitian terdahulu yang terkait dengan pembahasan prediksi menggunakan support vector machine yang telah banyak dilakukan oleh peneliti sebelumnya.

Tabel 1. Tinjauan Studi

\begin{tabular}{|c|c|c|c|c|c|}
\hline No & Peneliti & Tahun & Masalah Penelitian & Metode & Hasil \\
\hline & $\begin{array}{c}\text { Hany A. } \\
\text { Elsalamony dan } \\
\text { Alaa M. Elyasad }\end{array}$ & 2013 & $\begin{array}{l}\text { Menentukan Model } \\
\text { Prediksi Terbaik }\end{array}$ & $\begin{array}{c}\text { Multilayer } \\
\text { Perception } \\
\text { Neural } \\
\text { Network } \\
\text { (MLPNN) dan } \\
\text { Ross Quinlan } \\
\text { New Decision } \\
\text { Tree Model } \\
\text { (C5.0) }\end{array}$ & $\begin{array}{l}\text { efektivitas model C5.0 } \\
\text { mencapai kinerja yang } \\
\text { lebih baik dibandingkan } \\
\text { dengan MLPNN }\end{array}$ \\
\hline & $\begin{array}{c}\text { Hany A. } \\
\text { Elsalamony }\end{array}$ & 2014 & $\begin{array}{c}\text { menganalisa pengaruh } \\
\text { keberhasilan efektifitas } \\
\text { kampanye pemasaran } \\
\text { langsung dengan } \\
\text { mengidentifikasi } \\
\text { karakteristik utama } \\
\text { dari model yg } \\
\text { digunakan }\end{array}$ & $\begin{array}{l}\text { MLPNN, TAN, } \\
\text { LR dan C5.0 }\end{array}$ & $\begin{array}{l}\text { Hasil eksperimen telah } \\
\text { menunjukkan efektifitas } \\
\text { model C5.0 tetap } \\
\text { menjadi yang lebih baik } \\
\text { dibandingkan model lain }\end{array}$ \\
\hline & $\begin{array}{c}\text { Pin Lio, Xin } \\
\text { Zhang, dan Kun } \\
\text { Li, Yang Fu, } \\
\text { Mingyan Wang } \\
\text { dan Sensen } \\
\text { Wang }\end{array}$ & 2015 & $\begin{array}{c}\text { menentukan model } \\
\text { optimasi parameter } \\
\text { terbaik }\end{array}$ & $\begin{array}{c}\text { algoritma } \\
\text { nested real- } \\
\text { valued genetic } \\
\text { (NRGA) dan } \\
\text { SVM }\end{array}$ & $\begin{array}{l}\text { optimasi parameter yang } \\
\text { diusulkan yaitu NRGA } \\
\text { dapat mengembangkan } \\
\text { klasifikasi SVM dengan } \\
\text { akurasi klasifikasi } \\
\text { unggul karena efisiensi } \\
\text { yang luar biasa dan } \\
\text { kekuatan pencarian } \\
\text { yang konsekuen }\end{array}$ \\
\hline
\end{tabular}

Sumber: Hasil Penelitian (2016)

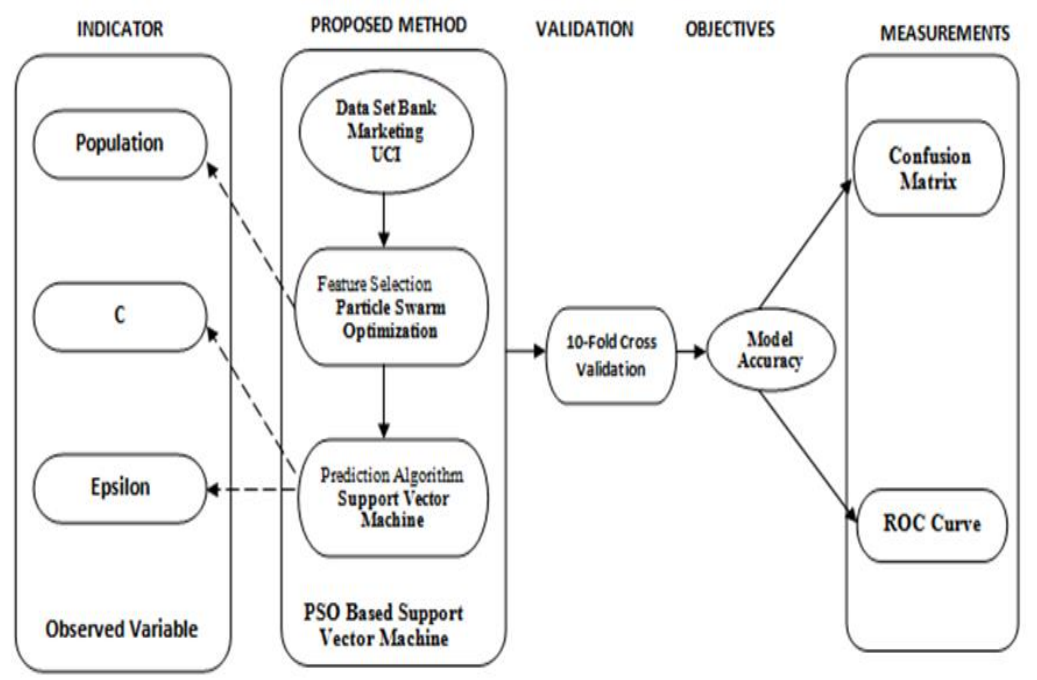

Gambar 3. Kerangka Pemikiran

Sumber: Hasil Penelitian (2016)

\section{Metode Penelitian}

Dalam konteks penelitian, metode yang dilakukan mengacu kepada pemecahan masalah yang meliputi mengumpulkan data, merumuskan hipotesis atau proposisi, pengujian 
hipotesis, menafsirkan hasil dan kesimpulan. Terdapat empat metode penelitian yang umumnya digunakan, diantaranya: Action Research, Experiment, Case Study dan Survei (Dawson, 2009).

Pada penelitian ini menggunakan metode penelitian eksperimen, yakni melibatkan penyelidikan perlakuan pada parameter atau variabel tergantung dari peneliti itu sendiri, dan menggunakan tes yang dikendalikan oleh si peneliti itu sendiri. Langkah-langkah yang dilakukan pada proses penelitian adalah sebagai berikut:

1. Pengumpulan Data

Data yang digunakan dalam penelitian ini adalah data yang terkait dengan kampanye pemasaran langsung (panggilan telepon) dari lembaga perbankan Portugis. Tujuan klasifikasi adalah untuk memprediksi jika klien berlangganan deposito berjangka. Data tersebut diperoleh dari https://archive.ics.uci.edu/ml/datasets/ Bank+Marketing\# (UCl, 2012). Data set berdasarkan dari data pemasaran bank dari lembaga perbankan portugis dari

bulan May 2008 sampai bulan November 2010.

2. Pengolahan awal data
a. Data validation, untuk mengidentifikasikan dan menghapus data yang ganjil (outlier/noise), data yang tidak konsisten, dan data yang tidak lengkap (missing value).

b. Data integration and
transformation, untuk meningkatkan akurasi dan efisiensi algoritma. Data yang digunakan dalam penulisan ini bernilai kategorikal.

c. Data size reduction and discritization, untuk memperoleh data set dengan jumlah atribut dan record yang lebih sedikit tetapi bersifat informative. Model yang diusulkan.

3. Eksperimen dan pengujian metode Tahap modeling untuk menyelesaikan prediksi pemasaran langsung dengan menggunakan dua metode yaitu algoritma support vector machine dan algoritma particle swarm optimization.

a. Support vector machine yaitu model untuk menemukan hyperplane terbaik yang memisahkan dua buah class.

b. Particle Swarm Optimization yaitu pencarian solusi optimal secara global dalam ruang pencarian melalui interaksi individu dalam segerombolan partikel dengan cara melakukan seleksi terhadap atribut yang ada.

4. Evaluasi dan validasi hasil

Setelah tahap modelling dilakukan, hasil dari model Algoritma Support Vector Machine dan Support Vector Machine berbasis Particle Swarm Optimization ini kemudian akan dilihat tingkat akurasinya menggunakan Confusion matrix dan nilai AUC (Area Under Curve) untuk mengetahui model/metode yang memiliki tingkat akurasi yang paling tinggi, sehingga tujuan penerapan model Algoritma Support Vector Machines dan Support Vector Machine berbasis Particle Swarm Optimization untuk klasifikasi pada prediksi pemasaran langsung akan tercapai.

\section{Hasil dan Pembahasan}

Tujuan dari penelitian ini adalah mengembangkan model yang sudah terbentuk dengan klasifikasi algoritma Support Vector Machine (SVM) dan menerapkan Particle Swarm Optimization (PSO) dengan melakukan seleksi atribut pada Support Vector Machine (SVM) untuk meningkatkan akurasi keakuratan model prediksi pemasaran langsung.

\subsection{Hasil Eksperimen dan Pengujian Metode}

3.1.1. Metode Support Vector Machine

Berikut adalah gambar pengujian algoritma Support Vector Machine (SVM) menggunakan metode K-Fold Cross Validation dengan menggunakan RapidMiner: 


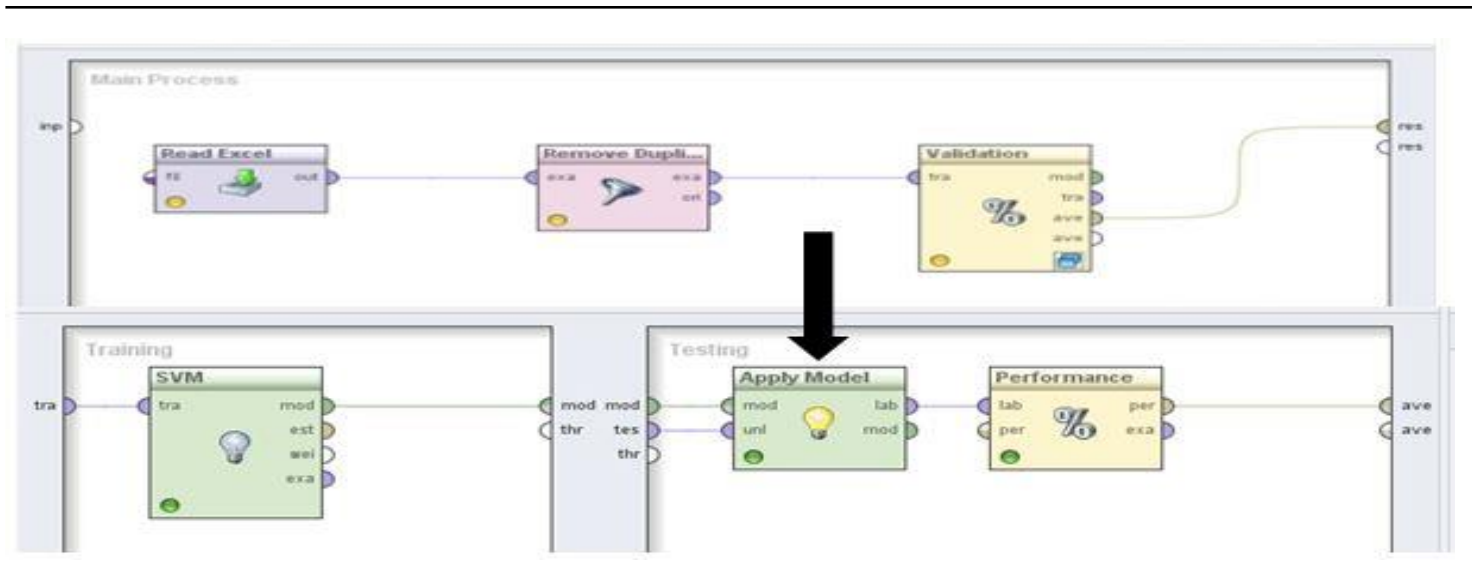

Gambar 4.

Pengujian K-Fold Cross Validation algoritma Support Vector Machine

Hasil terbaik pada eksperimen SVM diatas adalah $\mathrm{C}=1.0$ dan Epsilon $=0.0$ dihasilkan accuracy $88.71 \%$ dan AUC 0.896. Lalu diikuti SVM dengan $\mathrm{C}=0.0$ dan Epsilon=0.0 dihasilkan accuracy $88.50 \%$ dan AUC 0.895, kemudian SVM dengan $\mathrm{C}=1.0$ dan Epsilon=1.0 dihasilkan accuracy $81.20 \%$ dan AUC 0.500 .

\subsubsection{Metode Support Vector Machine berbasis Particle Swarm Optimization}

Berikut adalah gambar pengujian algoritma Support Vector Machine berbasis Particle swarm optimization menggunakan metode K-Fold Cross Validation dengan menggunakan RapidMiner:

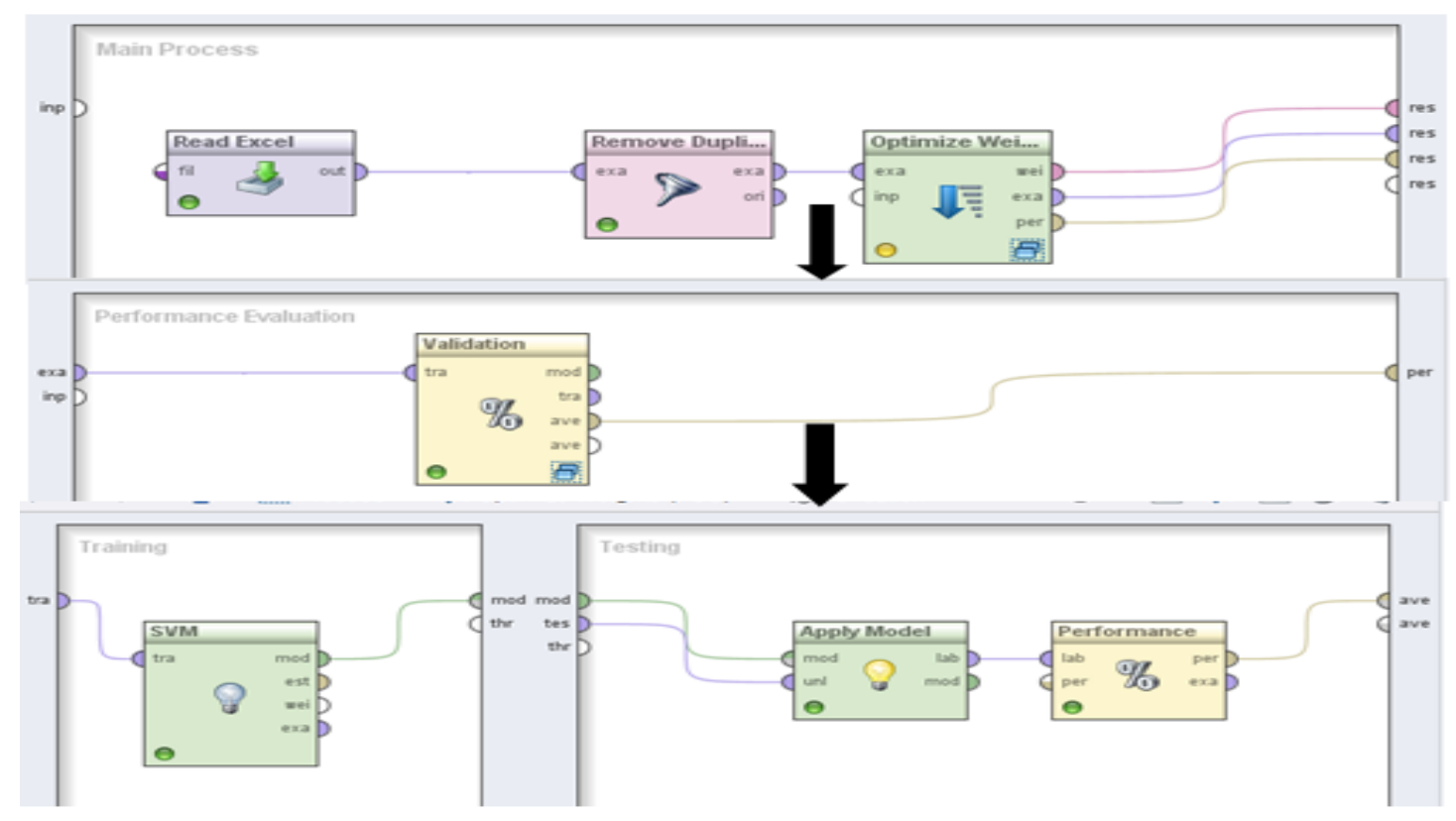

Gambar 5. Pengujian K-Fold Cross Validation algoritma Support Vector Machine berbasis PSO

Sumber: Hasil Penelitian (2016)

Hasil terbaik pada eksperimen SVM berbasis $\mathrm{PSO}$ diatas adalah dengan $\mathrm{C}=1.0$ dan Epsilon $=0.0$ yang diperoleh dengan hasil accuracy $89.38 \%$ dan AUCnya 0.909 . maka nilai-nilai tersebut yang akan digunakan dalam penelitian ini.

\subsection{Evaluasi dan Validasi Model}

3.2.1. Hasil pengujian metode Support Vector Machine

1. Confusion Matrix

Gambar 6 menunjukkan hasil dari confusion matrix metode support vector machine. Berdasarkan Gambar 6 dapat 
diketahui bahwa dari 452 data, 42 data diprediksikan yes sesuai dengan prediksi yang dilakukan dengan metode SVM, kemudian 8 data diprediksi yes tetapi ternyata hasilnya prediksi no. Kemudian

\begin{tabular}{|c|c|c|c|}
\hline \multicolumn{4}{|c|}{ (1) Multiclass Classification Performance $\bigcirc$ Annotations } \\
\hline \multicolumn{4}{|c|}{ (-) Tableview Oplotview } \\
\hline \multicolumn{4}{|c|}{ accuracy: $88.71 \%+1.4 .15 \%$ (mikro: 88.72\%) } \\
\hline & true yes & true no & class precision \\
\hline pred. yes & 42 & 8 & $84.00 \%$ \\
\hline pred. no & 43 & 359 & $89.30 \%$ \\
\hline class recall & $49.41 \%$ & $97.82 \%$ & \\
\hline
\end{tabular}

Gambar 6. Hasil Pengujian Confusion Matrix untuk Metode SVM Sumber: Hasil Penelitian (2016)

Hasil perhitungan terlihat pada tabel 2 dibawah ini:

Tabel 2. Nilai Accuracy, sensitivity, specificity, PPV dan NPV metode SVM

\begin{tabular}{|c|c|}
\hline & Nilai (\%) \\
\hline Accuracy & 88.71 \\
\hline Sensitivity & 84.00 \\
\hline Specificity & 89.30 \\
\hline PPV & 49.41 \\
\hline NPV & 97.82 \\
\hline
\end{tabular}

2. Kurva $R O C$

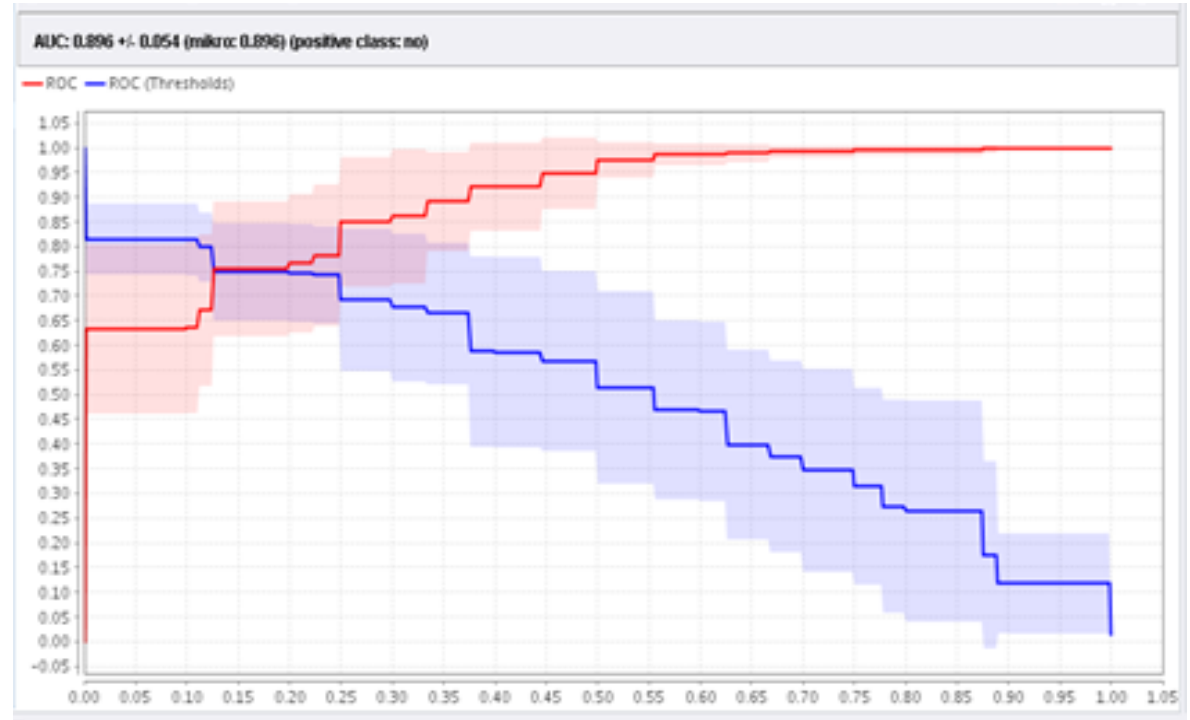

Gambar 7. Kurva ROC dengan Metode Support Vector Machine Sumber: Hasil Penelitian (2016) 
3.2.2. Hasil Pengujian Metode Support Vector Machine berbasis Particle Swarm Optimization

1. Confusion Matrix
Gambar 8 menunjukkan hasil dari confusion matrix metode support vector machine berbasis particle swarm optimization.

\begin{tabular}{|c|c|c|c|}
\hline \multicolumn{4}{|c|}{ O Table View Oplotview } \\
\hline \multicolumn{4}{|c|}{ accuracy: $89.389 \%+1.3 .824$ (mikro: 89.384) } \\
\hline & trueves & trueno & class precision \\
\hline pred. yes & 44 & $?$ & $86.27 \%$ \\
\hline pred. no & 41 & 360 & $89.78 \%$ \\
\hline class recall & $51.76 \%$ & $98.09 \%$ & \\
\hline
\end{tabular}

Gambar 8. Hasil Pengujian Confusion Matrix untuk Metode SVM berbasis PSO Sumber: Hasil Penelitian (2016)

Tabel 3. Nilai Accuracy, sensitivity, specificity, PPV dan NPV metode SVM berbasis PSO

\begin{tabular}{|c|c|}
\hline & Nilai (\%) \\
\hline Accuracy & 89.38 \\
\hline Sensitivity & 86.27 \\
\hline Specificity & 89.78 \\
\hline PPV & 51.76 \\
\hline NPV & 98.09 \\
\hline
\end{tabular}

2. Kurva $R O C$

Sumber: Hasil Penelitian (2016)

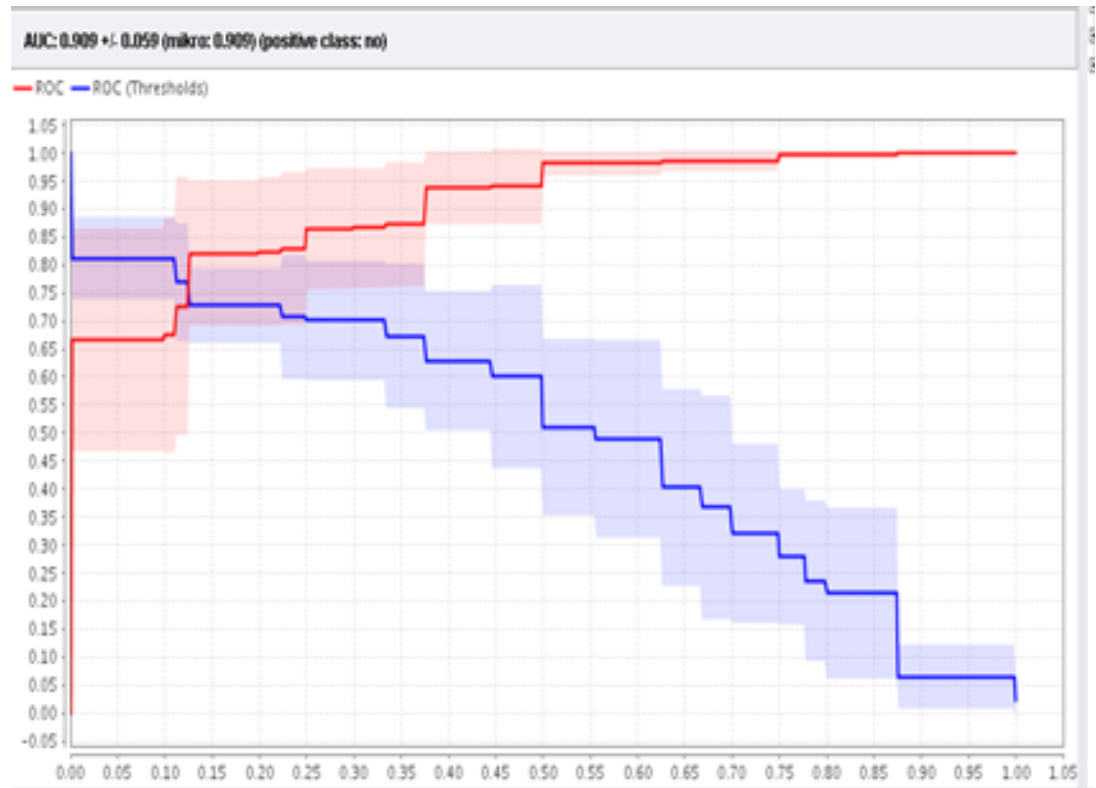

Gambar 9. Kurva ROC dengan Metode Support Vector Machine berbasis PSO Sumber: Hasil Penelitian (2016) 
3. Attribute Weight

Hasil Attribute Weight yang didapat dari penelitian ini adalah:

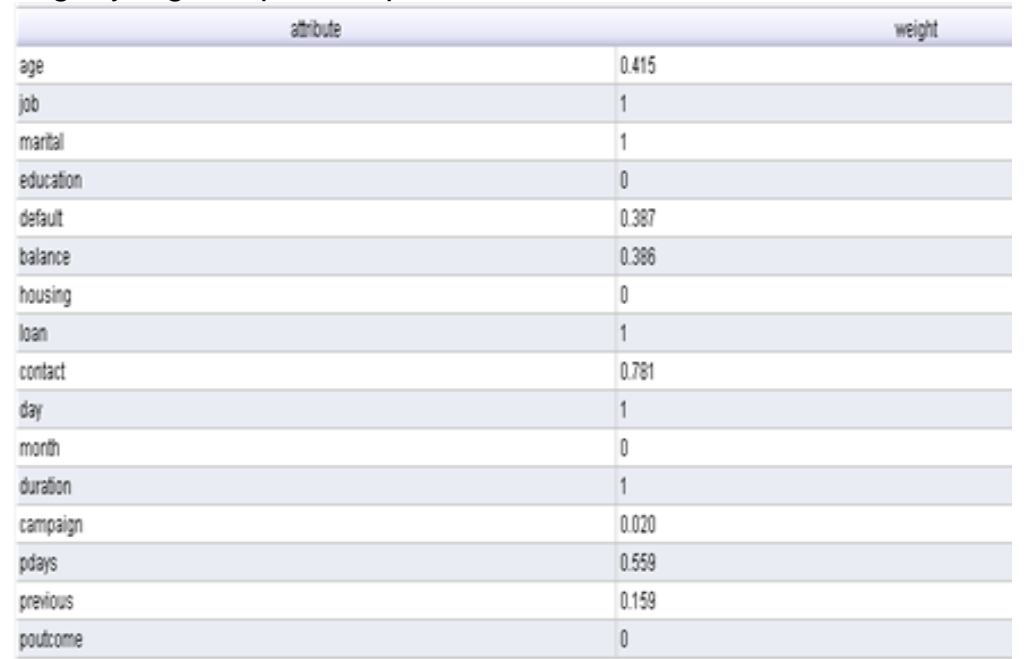

Gambar 10. Attribute Weight dengan Metode Support Vector Machine berbasis Particle Swarm Optimization

Sumber: Hasil Penelitian (2016)

\subsubsection{Analisa Evaluasi dan Validasi Model}

Hasil analisis dari metode algoritma Support Vector Machine dan Support Vector Machine berbasis Particle Swarm Optimization dirangkumkan dalam tabel dibawah ini.

Tabel 4. Komparasi Nilai Accuracy dan AUC

\begin{tabular}{|l|c|c|c|}
\hline & SVM & $\begin{array}{c}\text { SVM } \\
\text { Berbasi } \\
\text { s PSO }\end{array}$ & $\begin{array}{c}\text { Peningkata } \\
\mathbf{n}\end{array}$ \\
\hline $\begin{array}{l}\text { Accurac } \\
\boldsymbol{y}\end{array}$ & $\begin{array}{c}88.71 \\
\%\end{array}$ & $89.38 \%$ & $0.67 \%$ \\
\hline AUC & 0.896 & 0.909 & 0.013 \\
\hline
\end{tabular}

Sumber: Hasil Penelitian (2016)

Tabel 4. membandingkan Accuracy dan AUC dari tiap metode. Terlihat bahwa nilai accuracy dan AUC Support Vector Machine berbasis Particle Swarm Optimization memiliki nilai lebih tinggi dibandingkan Support Vector Machine tunggal. Penerapan Particle Swarm Optimization untuk optimasi prediksi pemasaran langsung menghasilkan peningkatan akurasi sebesar 0.67\% dan AUC sebesar 0.013 .

\subsection{Implikasi Penelitian}

Berdasarkan hasil pengujian diatas, dengan melakukan evaluasi baik secara confusion matrix maupun ROC curve, terbukti bahwa pengujian yang dilakukan menggunakan algoritma Support Vector Machine berbasis Particle Swarm Optimization (PSO) memiliki nilai akurasi yang lebih tinggi dibandingkan hanya dengan menggunakan algoritma Support Vector Machine (SVM) tunggal.

Hasil dari penelitian ini mempunyai implikasi terhadap pemasaran langsung yaitu meliputi implikasi terhadap aspek sistem pendukung keputusan pemsaran langsung, aspek manajerial, dan aspek terhadap penelitian-penelitian selanjutnya yang akan diuraikan dibawah ini:

1. Implikasi terhadap aspek sistem pendukung keputusan pemasaran langsung

Hasil evaluasi menunjukkan penerapan Particle swarm optimization (PSO) untuk seleksi atribut dalam Support Vector Machine (SVM) dan dilakukan penyesuaian pada parameter $C$ dan $\varepsilon$ mampu menunjukkan aspek berupa atribut yang berpengaruh terhadap hasil dari prediksi pemasaran langsung.

2. Implikasi terhadap aspek manajerial Dari hasil penelitian ini diketahui bahwa metode Support Vector Machine berbasis Particle swarm optimization dapat mendukung pengambilan keputusan dan pengembangan sistem informasi manajemen pada lembaga keuangan dan perbankan dengan menggunakan bantuan software RapidMiner. 
3. Implikasi terhadap penelitian-penelitian selanjutnya

Pengembangan dapat dilakukan dengan pemilihan parameter menggunakan metode Genetic Algorithm untuk meningkatkan hasil optimasi. Penggunaan algoritma yang lain juga dapat digunakan misalkan dengan metode Neural Network, C4.5, $K$-Nearest Neighbor dan sebagainya. Karena lembaga keuangan semakin berkembang maka kajian semacam ini dapat dilakukan secara periodik.

\section{Kesimpulan}

Pada penelitian ini dilakukan pengujian model dengan menggunakan Support Vector Machine dan Support Vector Machine berbasis Particle Swarm Optimization dengan menggunakan data yang terkait kampanye pemasaran langsung dari lembaga perbankan Portugis yang diperoleh dari UCl Repository tahun 2012. Model yang dihasilkan diuji untuk mendapatkan nilai accuracy dan AUC dari setiap algoritma sehingga didapat pengujian dengan menggunakan Support Vector Machine didapat nilai accuracy adalah $88.71 \%$ dan nilai AUC adalah 0.896. Sedangkan pengujian dengan mengunakan Support Vector Machine berbasis Particle Swarm Optimization dilakukan seleksi atribut dan penyesuaian pada parameter $C$ dan $\varepsilon$. Dari 16 variabel prediktor dilakukan seleksi atribut sehingga menghasikan terpilinnya 12 atribut yang digunakan dan didapatkan nilai accuracy 89.38\% dengan nilai AUC adalah 0.909 Maka dapat disimpulkan pengujian dataset bank (pemasaran langsung) menggunakan Support Vector Machine dan penerapan Particle Swarm Optimization dalam pemilihan atribut didapat bahwa metode tersebut lebih akurat dalam penentuan prediksi pemasaran langsung dibandingkan dengan metode Support Vector Machine tunggal, hal ini ditandai dengan peningkatan nilai akurasi sebesar $0.67 \%$ dan nilai AUC sebesar 0.013 , dan nilai tersebut masuk kedalam klasifikasi akurasi sangat baik (excellent classification).

Berdasarkan proses pengujian dan kesimpulan yang telah dilakukan, maka ada beberapa saran dalam penelitian ini adalah:

1. Menambahkan jumlah data yang lebih besar dan atribut yang lebih banyak, sehingga hasil pengukuran yang akan didapatkan lebih baik lagi.

2. Menggunakan metode optimasi lain seperti Adaboost, Ant Colony Optimization (ACO), Genetik Algorithm (GA), dan lainnya.

3. Melakukan pengembangan dengan menggunakan metode seleksi atribut yang lain seperti chi-square, information index dan sebagainya untuk ketepatan penyeleksian atribut.

4. Meningkatkan lagi faktor sistem prediksi pemasaran langsung untuk penentuan nasabah yang akan berlangganan deposito dan analisis data pribadi nasabah.

\section{Referensi}

Aydin, I., Karakose, M., \& Akin, E. (2011). A multi-objective artificial immune algorithm for parameter optimization in support vector machine. Journal Applied Soft Computing(11), 120-129.

Bellotti, T., \& Crook, J. (2007). Support vector machines for credit scoring and discovery of significant features. Expert System with Application: An International Journal(36), 3302-3308.

Dawson, C. W. (2009). Project in Computing and Information System A Student's Guide. England: Addison-Wesley.

Elsalamony, H. (2014). Bank Direct Marketing Analysis of Data Mining Techniques. International Journal of Computer Applications, 09758887 Volume 85 - No. 7.

Elsalamony, H. A., \& Elsayad, A. M. (2013, Agustus). Bank Direct Marketing Based on Neural Network and C5.0 Models. IJEAT, II(6), 392-400.

Han, J., \& Kamber, M. (2007). Data Mining Concepts and technique. San Francisco, USA: Diane Cerra.

Kotler, P., Armstrong, G., Ang, S. H., Leong, S. M., Tan, C. T., \& Tse, D. K. (2005). Principles Of Marketing An Asian Perspective. Kuala Lumpur: Prentice Hall; 11TH EDITION edition. 
Maimon, O., \& \& Rokach, L. (2010). Data Mining and Knowledge Discovery Handbook (2nd ed). New York: Springer Dordrecht Heidelberg London.

Moro, S., \& Laureano, R. M. (2012). Using Data Mining for Bank Direct Marketing: An application of the CRISP-DM methodology. European Simulation and Modelling Conference, Figure I, 117-121.

UCI. (2012, Februari 14). Retrieved from $\mathrm{UCl}$ Machine Learning Repository: https://archive.ics.uci.edu/ml/datase ts/bank+marketing

Vercellis, C. (2009). Business Intelegent: Data Mining and Optimization for Decision Making. Southern Gate, Chichester, West Sussex: john Willey \& Sons, Ltd.

Yin, H., X., J., Chai, Y., \& Fang, B. (2015). Scene classification based on single-layer SAE and SVM. Expert Systems with Applications, 7(42), 3368-3380.

Yusup, N., Zain, A. M., Zaiton, S., \& \& Hashim, M. (2012). Prosedia Engeneering Overview of PSO for Optimizing Process Parameters of Machining. Elsevier. 